- COMMENTARY

Volume 8 Issue 32016

DOl: 10.5959/eimj.v8i3.455

ARTICLE INFO

Submitted: 01-08-2016

Accepted: 11-08-2016

Online: 30-09-2016

\section{Tailoring Teaching Instructions According to Student's Different Learning Styles: Are We Hitting the Right Button?}

\author{
Keng Sheng Chew \\ Faculty of Medicine and Health Sciences, Universiti Malaysia \\ Sarawak, Malaysia
}

To cite this article: Chew KS. Tailoring teaching instructions according to student's different learning styles: are we hitting the right button? Education in Medicine Journal. 2016;8(3):103-107. http:// dx.doi.org/10.5959/eimj.v8i3.455

To link to this article: http://dx.doi.org/10.5959/eimj.v8i3.455

\title{
ABSTRACT
}

To address the diverse preferred learning styles, one of the oft-cited recommendations for educators is to tailor teaching instructions accordingly. This pedagogy however, lacks scientific evidences. Furthermore, in medical curriculum, tailoring instructions according to preferred learning styles is not pragmatic. This is because different subjects and in different settings matter may be best delivered in specific delivery mode. Furthermore, patients' presentations are often multi-sensorial. As such, the onus is on the students themselves to adjust the amount of learning efforts they put in according to their preferred or not preferred learning styles.

Keywords: Learning styles, Fleming's VARK model, Teaching instructions, Meshing hypothesis, Medical curriculum

CORRESPONDING AUTHOR Keng Seng Chew MD, MMED (Emergency Midicine), Professor/Emergency Physician, Department of Surgery, Faculty of Medicine and Health Sciences, Universiti Malaysia Sarawak, 94300 Kota Samarahan, Sarawak, Malaysia | Email: kschew@unimas.my

\section{Introduction}

One of the oft-quoted elements in student diversity is the different preferred learning styles among students. A number of theories on learning styles have been put forth but the common denominator undergirding all these theories is the notion that different people learn and think differently and therefore, learning can be optimised if the pedagogy is tailored accordingly (1). An early model on learning style is called the experiential learning model developed by David Kolb. Kolb described learning as "the process whereby knowledge is created through the transformation of experience" (2). He also outlined four learning styles, viz., the divergers, the assimilators, the convergers and the accommodators (see Table 1 for brief descriptions of these four learning styles) and outlines six learning propositions (2):

1. Learning is best conceived as a process, not in terms of outcomes.

2. Learning is a continuous process grounded in experience.

3. Learning requires the resolution of conflicts between dialectically opposed modes of adaptation to the world.

4. Learning is a holistic process of adaptation.

5. Learning results from synergistic transactions between the person and the environment.

6. Learning is the process of creating knowledge 
Table 1: Kolb's learning styles according to the Experiential Learning Model $(2,7)$

\begin{tabular}{ll}
\hline \multicolumn{1}{c}{ Learning style } & \multicolumn{1}{c}{ Descriptions } \\
\hline The diverger & $\begin{array}{l}\text { A learner who learns from concrete experiences by reflectively observes these } \\
\text { experiences from different perspectives. The strength of the diverger lies in his } \\
\text { or her imaginative and creative abilities to relate with others. Hence, this learner } \\
\text { is somebody who is more inclined to work in groups, has strong communication } \\
\text { skills, and is open to personal feedback. } \\
\text { A learner who learns from abstract conceptualisation and then finds practical } \\
\text { applications of the ideas that he or she has learned. This learner is proficient in } \\
\text { solving new problems because he or she likes to find practical applications of the } \\
\text { ideas learned. The strength of this learner lies in with the ability to set goals and } \\
\text { solve problems or make decisions using first hand experiences. This learner prefers } \\
\text { to deal with technical problems rather than interpersonal issues, and hence, is able } \\
\text { to control the expression of emotions well. } \\
\text { A learner who learns from both concrete experiences and active experimentations. } \\
\text { The strength of this learner lies in the ability to implement plans and tasks and then } \\
\text { becomes actively involved in these new activities. This learner likes challenges and } \\
\text { often makes decisions based on intuition than logic. } \\
\text { A learner who learns from both abstract conceptualisations and reflective } \\
\text { observations. The strength of lies in the ability to systematically plan, organise and } \\
\text { analyse in the most logical form. He or she prefers information that is logical, valid, } \\
\text { and well thought through. }\end{array}$ \\
\hline
\end{tabular}

To determine an individual's learning style, Kolb also developed the Learning Style Inventory (LSI), which has subsequently been revised over the years to the current 48item scale.

Subsequently, Honey and Mumford adapted Kolb's experiential learning model for the business community and came up with their own Learning Style Questionnaire (LSQ) to determine the best fit for their four types of learners in the business community, i.e., the activist, the reflector, theorist as well as the pragmatist (2). The rationale for this development is that Honey and Mumford noted that within the context of the business community, Kolb's LSI lacks the face validity $(2,3)$. This is because Kolb's LSI probes the underlying construct of learning psychology (something which business community rarely do!) rather than the observable behaviours that reflect the types of learning styles $(2,3)$.

But perhaps the most familiar learning style model is the VARK model by Fleming (4). In this self-explanatory model, Fleming describes four types of learners, i.e., the visual (V) learner, the auditory (A) learner, the reading $(\mathrm{R})$ learner and the kinesthetic (K) learner $(3,4)$.

\section{Addressing the Assumptions in the Meshing Hypothesis}

Back to the issue of addressing this diversity of learning styles among students, one of the common recommendations often cited is for educators to tailor their instruction modes to one that best matches the learner's styles (assuming that the learner knows what is their preferred learning style and that this preferred learning style is the best one for him or her). This preferential model concept is also known as the meshing hypothesis (5).

But are these assumptions true? Do students really know what their preferred learning styles are? And if they do attempt to find out their preferred learning styles through one of these learning style inventories as described above (e.g. the LSI), are these inventories valid and reliable across the board? In other words, do these inventories measure what they are 
intended to measure? Are the learning styles that the students prefer really the best ones for them? Is there any scientific evidence to support the meshing hypothesis, namely, if a lesson is delivered in the mode that is in alignment with the preferred learning style of the student, the student would perform better in examination? This commentary attempts to unravel some of these questions from two perspectives, viz., the scientific perspective and the pragmatic perspective, using the undergraduate medical curriculum as a framework for discussion.

\section{The Scientific Perspective}

Willingham, Hughes \& Dobolyi (2015) in their review on the scientific status of learning styles theories, quoted at least nine sources spanning over a period of four decades that show no good evidence to support the theory that learners learn best in their preferred learning styles (1). For example, as early as in 1979, Arter and Jenkins, in their review on 14 studies found no evidence that matching children to their preferred learning styles improved their learning outcomes (6). Similarly, in a metaanalysis by Kavale and Forness involving 39 studies found that matching children according to their learning styles had very minimal effect on their achievement (7). And within the context of medical curriculum, Cook et al. in a randomised controlled study involving 123 internal medicine residents, found no evidence that adapting instructions in accordance to the learners' learning styles actually improved learning outcomes (8). This lack of evidentiary support for such meshing hypothesis is further compounded by the fact that even the inventories used to determine the learner's learning styles lack the expected validity and reliability (3).

As pointed out by Kirschner and van Merriënboer, to determine learners' learning styles, almost always, self-reported inventories are used (9). And whenever self-reported inventories are used, there is always a concern of the lack of reliability and the effects of personal biases because people often do not or are not willing to report honestly (9). Massa and Mayer for example, found that the self-reported learning style preference actually had a very weak relationship with the learner's objectively measured actual learning outcomes (10). Worse still, in a meta-analysis by Clark, it was found that the learner's preferred learning style not only had poor correlation but negative correlation with the learner's learning achievements (11). In other words, what people prefer is often not what the best is for them. In fact, Kirschner and van Merriënboer went to the extent of saying that tailoring instructions according to the preferred rather than the best learning styles is akin to the analogy of a child who prefers candy and soft drinks over milk and fruit (9). Just because a child prefers candy and soft drinks rather than milk and fruit, would a parent give this child what he or she prefers?

\section{The Pragmatic Perspective}

Therefore, pigeonholing students, particularly medical students according to one form of learning style over another is neither realistic nor helpful. It is not realistic because most people do not fit neatly into one of these learning styles. Rather, most people have a mixture of two or more preferred learning that differ in their degree of inclination on a continuum scale (9). Tailoring lessons according to the students' preferred learning styles is therefore, not a practical thing to do.

It is also not helpful because different subject matter and in different setting (e.g., operation theater, tutorial room, clinic, etc.) may call for different learning styles. Dermatology, for example, would best be delivered through a predominant visual delivery mode whereas psychiatry would require the execution of a greater degree of auditory learning style as it involves listening to the relatively long histories from the patients and their relatives.

Furthermore, patient's disease presentation is often multi-sensorial. A jaundiced patient may present with visibly yellowish discoloured sclera, an asthmatic patient may present with audibly loud wheeze and 
a patient with acute abdomen may present with a palpably tender abdomen. It would be naive for a medical student to say that just because he or she prefers the auditory learning style, he or she would best learn the different dermatologic conditions by just listening to the descriptions of these skin lesions without actually attempting to see pictures of these skin lesions. It would spell a greater disaster if, upon graduation, a house officer gives that the excuse for not picking up a heart murmur by saying that he or she is a very poor auditory learner and therefore, did not learn the heart murmurs well while in medical school. Medical students have no choice but to learn through the different types of learning styles for different subject matters and in different settings.

\section{Conclusion}

In conclusion, how then shall we address the diversity of preferred learning styles among medical students? We cherish them. And we make students aware of this. We cherish them because precisely this diversity is what makes a class interesting. It means that there may be students who will eventually graduate being a dermatologist, a surgeon, a physician, a psychiatrist, an emergency physician, etc. And we make them aware of their own vulnerabilities so that they can put greater remedial effort in subject matters that they are weak in because these subject matters require a greater degree of the types of learning styles that they are not so inclined to. But to tailor medical education instructions according so that the students' preferred learning styles is neither scientific nor pragmatic. The onus is on the students to adjust the amount of learning efforts they put in according to their preferred or not preferred learning styles.

\section{References}

1. Willingham DT, Hughes EM, Dobolyi DG. The scientific status of learning styles theories. Teaching of Psychology. 2015; 42(3):266-71. http://dx.doi.org/10.1177/009 8628315589505 .
2. Manolis C, Burns DJ, Assudani R, Chinta R. Assessing experiential learning styles: a methodological reconstruction and validation of the Kolb learning style inventory. Learning and Individual Differences. 2013; 23:44-52. http://dx.doi.org/10.1016/j.lindif. 2012.10.009.

3. Coffield F, Moseley D, Hall E, Ecclestone $\mathrm{K}$. Learning styles and pedagogy in post16 learning: a systematic and critical review. London: Learning \& Skills Research Centre; 2004.

4. Fleming ND. I'm different; not dumb. Modes of presentation (VARK) in the tertiary classroom. In: Zelmer A, editor. Research and development in higher education. Proceedings of the 1995 Annual Conference of the Higher Education and Research Development Society of Australasia (HERDSA), HERDSA; 1995. Volume 18, p. 308-313.

5. Pashler $\mathrm{H}, \mathrm{McDaniel} \mathrm{M}$, Rohrer D, Bjork R. Learning styles: concepts and evidence. Psychological Science in the Public Interest. 2008;9(3):105-19.

6. Arter JA, Jenkins JR. Differential diagnosisprescriptive teaching: a critical appraisal. Review of Educational Research. 1979; 49(4):517-55. http://dx.doi.org/10.3102/003 46543049004517 .

7. Kavale KA, Forness SR. Substance over style: assessing the efficacy of modality testing and teaching. Exceptional Children. 1987;54(3):228-39.

8. Cook DA, Thompson WG, Thomas KG, Thomas MR. Lack of interaction between sensing-intuitive learning styles and problemfirst versus information-first instruction: a randomized crossover trial. Advances in Health Sciences Education: Theory and Practice. 2009;14(1):79-90. http://dx.doi. org/10.1007/s10459-007-9089-8.

9. Kirschner PA, van Merriënboer JJG. Do learners really know best? urban legends in education. Educational Psychologist. 2013;48(3):169-83. http://dx.doi.org/10.108 0/00461520.2013.804395. 
10. Massa LJ, Mayer RE. Testing the ATI hypothesis: should multimedia instruction accommodate verbalizer-visualizer cognitive style? Learning and Individual Differences. 2006;16(4):321-35. http://dx.doi.org/10. 1016/j.lindif.2006.10.001.
11. Clark RE. Antagonism between achievement and enjoyment in ATI studies. Educational Psychologist. 1982;17(2):92-101. http://dx. doi.org/10.1080/00461528209529247. 
